\title{
Persepsi Remaja Terhadap Kesan Menakutkan Pada Peringatan Kesehatan Bergambar Di Bungkus Rokok Ditinjau Dari Extended Parallel Process Model
}

\author{
Teenage Smokers' Perception of Scary Images on Pictorial Health Warnings Based \\ on the Extended Parallel Process Model
}

\author{
Andi Annisa Dwi Rahmawati*, Rita Damayanti*, Dien Anshari*
}

Departemen Pendidikan Kesehatan dan Ilmu Perilaku, Fakultas Kesehatan Masyarakat Universitas Indonesia (email penulis korespondensi: ritads@ui.ac.id)

\begin{abstract}
ABSTRAK
Latar Belakang. Tujuan pencantuman Peringatan Kesehatan Bergambar (PKB) pada bungkus rokok adalah mencegah remaja dari kebiasaan merokok. Dengan melihat gambar menakutkan pada PKB, remaja perokok juga diharapkan termotivasi berhenti merokok.

Tujuan. Penelitian ini bertujuan untuk mengetahui bagaimana pesan persuasif yang berusaha memunculkan rasa takut berperan dalam proses penerimaan atau penolakan pesan pada siswa yang pernah mendapat intervensi program berhenti merokok bernama Not on Tobacco (NOT) dengan yang belum pernah mendapatkannya.

Metode. Penelitian ini adalah penelitian kualitatif dengan desain Rapid Asessment Procedures (RAP). Metode yang digunakan dalam pengumpulan data adalah wawancara mendalam.

Hasil. Hasil penelitian menunjukkan siswa yang mendapat intervensi program berhenti merokok memiliki keyakinan diri yang lebih tinggi untuk dapat mengurangi konsumsi rokok atau berhenti merokok dengan mudah dibandingkan siswa yang tidak mendapat intervensi. Mereka yang mendapat intervensi juga menunjukkan penerimaan pesan paling baik. Hal ini terlihat dari perubahan niat, sikap, dan perilaku informan ke arah yang positif, berkaitan dengan perilaku merokok. Sementara itu, siswa yang tidak mendapat intervensi menunjukkan penolakan pesan akibat tidak dapat mengendalikan rasa takut. Hal ini tercermin dari perilaku siswa yang menghindari melihat PKB.
\end{abstract}

Kata kunci: psikologi, komunikasi, label peringatan, pengendalian tembakau, kebijakan

\section{ABSTRACT}

Background. Pictorial Health Warnings (PHWs) on cigarette packs are intended to prevent teenagers from smoking. However, little is known on how teenage smokers perceive the scary images on PHWs.

Objective. To explore how fear appeal strategy progresses to the acceptance or rejection of the messages among teenage smokers who had completed a smoking cessation program and among those who never join such program.

Method. This qualitative study used the Rapid Assessment Procedures (RAP) design, collecting data through in-depth interviews with 12 teenage smokers from one public and one private high schools.

Results. Participants who received intervention had higher self-confidence to reduce cigarette consumption and to quit smoking easily than those who did not receive the intervention. Those who received the intervention also showed a good acceptance of the messages in PHWs as reflected in their positive attitude and higher intention to quit smoking. Participants who did not receive the intervention showed rejection of the messages because they could not control the fear that aroused and prefer to avoid seeing the PHWs.

Keywords: psychology, communication, warning label, tobacco control, policy 


\section{LATAR BELAKANG}

Studi Pusat Penelitian Kesehatan Universitas Indonesia pada 2012 mengenai penyalahgunaan dan peredaran gelap narkoba pada kalangan pelajar/mahasiswa mengungkapkan 39,7\% siswa Sekolah Menengah Atas (SMA) di kota Depok pernah mencoba merokok, sedangkan proporsi siswa SMA yang dalam setahun terakhir merokok adalah $33,7 \% .{ }^{1}$ Guna membantu remaja perokok berhasil berhenti merokok, Pusat Penelitian Kesehatan Universitas Indonesia bekerja sama dengan Dinas Kesehatan dan Dinas Pendidikan Kota Depok menyelenggarakan program berhenti merokok bernama Not on Tobacco (NOT) di SMA Yapemri dan SMKN 2 pada tahun 2013. Program ini terbukti berhasil karena $88 \%$ partisipan dapat mengurangi jumlah konsumsi rokoknya. Jumlah tersebut berkurang dari 4,84 menjadi 3,04 batang per hari. ${ }^{2}$

Dalam rangka mengatasi epidemi tembakau, pemerintah mengeluarkan Peraturan Pemerintah Nomor 109 Tahun 2012 tentang Pengamanan Bahan yang Mengandung Zat Adiktif berupa Produk Tembakau bagi Kesehatan. Dalam Pasal 17 tercantum bahwa perusahaan rokok wajib mencantumkan pictorial health wearning atau peringatan kesehatan bergambar (PKB) dalam setiap kemasan rokok yang dijual. Kewajiban pencantuman PKB ini resmi diberlakukan sejak 24 Juni 2014 dengan luas tampilan PKB sebesar $40 \%$ di bagian depan dan $40 \%$ di bagian belakang kemasan rokok. ${ }^{3}$

Untuk putaran pertama, pemerintah melalui Permenkes Nomor 28 Tahun 2013 telah menetapkan lima gambar, yaitu gambar kanker mulut, gambar orang merokok dengan asap yang membentuk tengkorak, gambar kanker tenggorokan, gambar orang merokok dengan anak didekatnya, dan gambar paruparu yang menghitam karena kanker. ${ }^{4}$ Tiga dari lima PKB di putaran pertama menggunakan gambar menyeramkan berupa penyakit kanker. Ketiga gambar tersebut berusaha memunculkan rasa takut para perokok terhadap akibat merokok. Dengan munculnya rasa takut, diharapkan para perokok menerima pesan yang ada dalam PKB. Penerimaan pesan tersebut dapat dilihat, antara lain dengan sikap para perokok yang berubah menjadi negatif terhadap kebiasaan merokok, munculnya niat para perokok untuk berhenti merokok, atau bahkan keputusan perokok untuk berhenti merokok.

Pada kenyataannya, strategi menakutnakuti tak selamanya berhasil membuat seseorang menerima pesan yang disampaikan. Para perokok mungkin saja menolak pesan yang ada dalam PKB dengan menunjukkan pengelakkan terhadap gambar penyakit yang ditimbulkan akibat merokok atau menganggap gambar penyakit tersebut terlalu dilebihlebihkan.

Studi pendahuluan peneliti di bulan Januari 2015 pada beberapa siswa SMA di Kota Depok menunjukkan para siswa perokok menganggap gambar penyakit (kanker mulut, kanker tenggorokkan, dan kanker paru) pada PKB yang kini beredar terlalu dilebihlebihkan. Mereka mengaku tahu dan menyadari bahaya merokok, namun merasa dirinya tidak rentan terkena penyakit tersebut karena usianya yang masih muda. Selain itu, para siswa menganggap rokok telah menjadi bagian dari keseharian hidupnya sehingga sulit untuk berhenti merokok.

Dengan pendekatan kualitatif, peneliti ingin menggali lebih dalam bagaimana siswa SMA Yapemri dan SMKN 2 yang mendapat intervensi NOT dan yang tidak mendapat intervensi, memproses kesan menakutkan dalam PKB. Peneliti juga ingin mengetahui apakah tema-tema yang muncul akan senada dengan komponen yang ada dalam Extended Parallel Process Model (EPPM) dari Kim Witte. Penelitian ini penting dilakukan untuk menjelaskan kapan dan bagaimana strategi menakut-nakuti dalam PKB berhasil atau gagal pada tiap siswa. 


\section{Tinjauan Teoritis}

Penelitian ini menggunakan Extended Parallel Process Model (EPPM) dari Kim Witte sebagai kerangka konsep. Model ini menggabungkan beberapa penelitian sebelumnya mengenai starategi menakutnakuti (fear appeal), kemudian berusaha menjawab mengapa strategi tersebut kadang berhasil dan kadang pula gagal. Kelebihan dari EPPM adalah peneliti dapat mengetahui kapan dan bagaimana strategi menakut-nakuti berhasil atau gagal pada tiap orang. Struktur model ini juga mudah dimengerti dan dapat menjadi panduan dalam meneliti banyak kampanye kesehatan masyarakat. ${ }^{5}$

Seperti disarikan dari Witte (1992), Witte (1994), dan Popova (2012), EPPM terdiri dari komponen kesan menakutkan, rasa takut, persepsi terhadap ancaman (terdiri dari persepsi terhadap keparahan dan persepsi terhadap kerentanan), efficacy (terdiri dari selfefficacy dan responseefficacy), dan tiga jenis respons (kontrol bahaya, kontrol rasa takut, dan tidak ada respons). ${ }^{5,6,7}$

Berikut penjelasan untuk tiap komponen:

a. Kesan menakutkan (fear appeal) Kesan menakutkan adalah pesan persuasif yang berusaha memunculkan rasa takut dengan menggambarkan ancaman serius yang mungkin terjadi pada seseorang. Pesan tersebut juga menampilkan rekomendasi yang mudah dan efektif dilakukan seseorang dalam rangka menghindari ancaman.

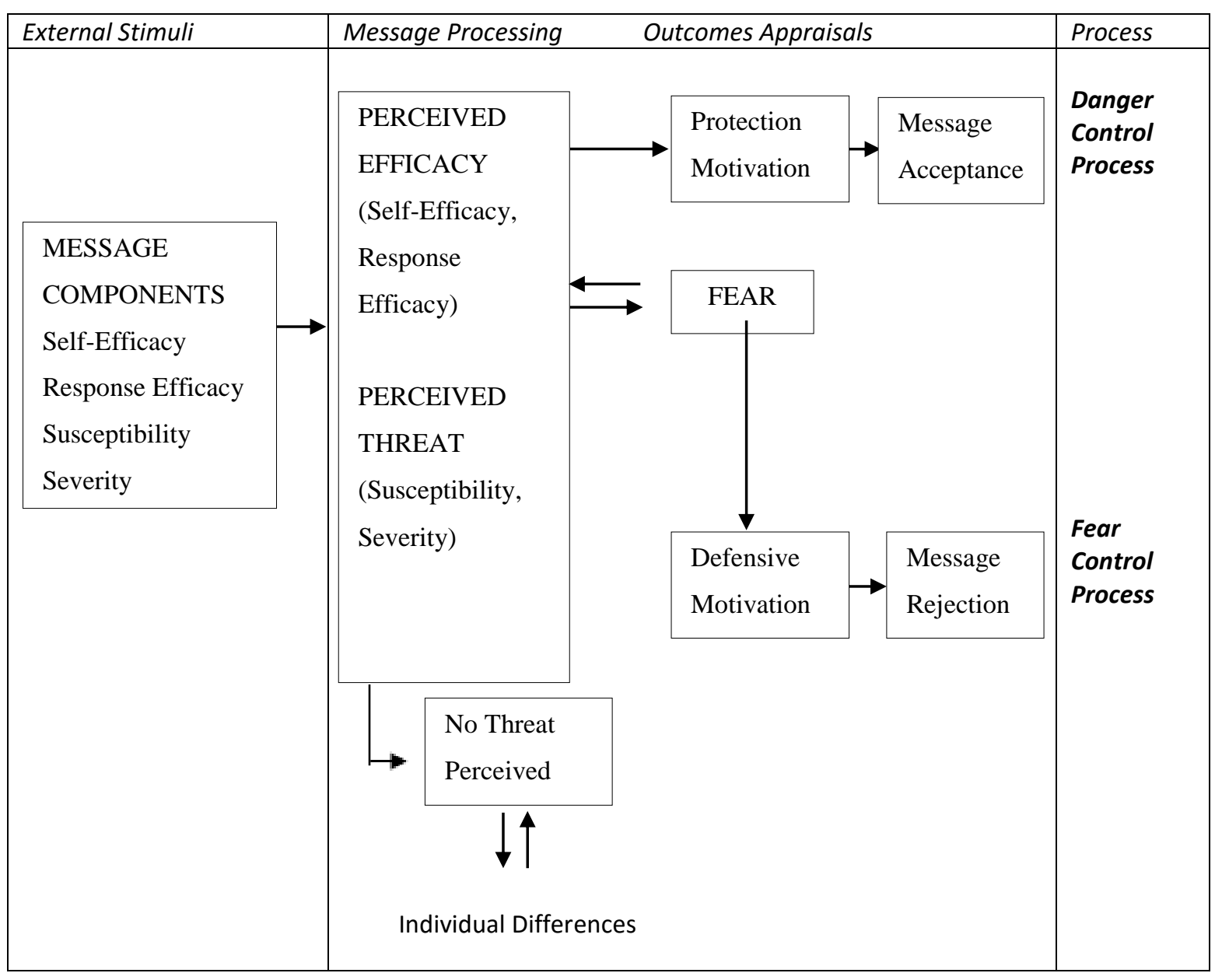

Gambar 1. Extended Parallel Process Model ${ }^{5}$ 
b. Rasa takut (fear)

Rasa takut didefinisikan sebagai reaksi emosional negatif terhadap sebuah ancaman. Dalam penelitian, rasa takut dinilai berdasarkan seberapa menyeramkan atau mengkhawatirkan sebuah ancaman bagi seseorang.

c. Ancaman

Secara konseptual, EPPM membedakan antara ancaman sebagai komponen dalam pesan dan ancaman sebagai persepsi yang dirasakan individu. Ancaman sebagai komponen pesan menekankan pada seberapa seram gambar atau pesan mengenai keparahan sebuah ancaman bagi populasi dan kerentanan populasi mengalami ancaman tersebut. Sedangkan persepsi terhadap ancaman merupakan evaluasi subjektif individu terhadap ancaman yang ada di dalam pesan. Persepsi terhadap ancaman terdiri dari dua dimensi, yaitu persepsi terhadap keparahan dan persepsi terhadap kerentanan.

Persepsi terhadap keparahan adalah keyakinan mengenai besaran, keseriusan, atau keparahan sebuah ancaman.

Contohnya, "Kanker paru dapat menyebabkan kematian." Sedangkan persepsi terhadap kerentanan adalah keyakinan seseorang mengenai risiko dirinya ancaman tersebut. Contohnya, "Saya berisiko terkena kanker paru karena merokok."

d. Efficacy

Dalam EPPM, konsep efficacy juga dibedakan antara efficacy sebagai karakteristik pesan dan perceived efficacy. Efficacy sebagai karakterisitik pesan terdiri dari response efficacy dan self-efficacy. Response efficacy adalah pesan dapat menunjukkan efektivitas sebuah tindakan untuk mencegah ancaman, sedangkan selfefficacy adalah informasi mengenai kemampuan khalayak untuk melakukan tindakan yang direkomendasikan.

Perceived efficacy didefinisikan sebagai kesadaran khalayak mengenai efektivitas, kemungkinan, dan kemudahan tindakan yang direkomendasikan guna meminimalisir atau menghindari ancaman. Komponen ini terdiri dari perceived response efficacy dan perceived selfefficacy. Perceived response efficacy adalah keyakinan mengenai seberapa efektif tindakan yang direkomendasikan. Contohnya, "Saya sangat yakin kanker paru dapat dihindari dengan berhenti merokok." Perceived self-efficacy adalah keyakinan tentang kemampuan individu melakukan tindakan yang direkomendasikan. Contohnya, "Saya mampu berhenti merokok."

e. Respon

Dalam EPPM terdapat tiga jenis respons yang mungkin dialami seseorang setelah melihat pesan dengan kesan menakutkan. Ketiga respons tersebut adalah konrtrol bahaya (danger control), kontrol rasa takut(fear control), dan tidak ada respons (no response).

Kontrol bahaya adalah proses kognitif yang mendorong seseorang melindungi dirinya karena ia percaya dapat mencegah ancaman yang mungkin terjadi. Ketika berada dalam situasi kontrol bahaya, seseorang akan mengembangkan motivasi protektif (protection motivation)yang ditandai dengan perubahan sikap, niat, atau perilaku sehubungan dengan pesan yang direkomendasikan. Contoh:

- Perubahan sikap: "Dengan mengurangi jumlah rokok yang dihisap, saya akan hidup lebih sehat."

- Perubahan niat: "Saya berencana mengurangi konsumsi rokok dengan menghubungi layanan konseling berhenti merokok."

- Perubahan perilaku: "Saat ini konsumsi rokok saya sudah berkurang setelah menghubungi layanan konseling berhenti merokok."

Tidak seperti kontrol bahaya yang merupakan proses kognitif, kontrol rasa takut adalah proses emosional yang terjadi ketika seseorang dihadapkan pada ancaman dan orang tersebut merasa tidak dapat 
melakukan apapun untuk mengatasinya. Ketika berada dalam situasi kontrol rasa takut, seseorang akan mengembangkan motivasi defensif (defensive motivation)yang ditandai dengan defensive avoidance, message minimization, atau perceived manipulation. Contoh:

- Defensive avoidance: "Ketika melihat gambar kanker mulut akibat merokok, saya hanya membuang waktu secara percuma."

- Message minimization: "Pesan mengenai kanker mulut ini terlalu dilebihlebihkan."
- Perceived manipulation: "Pesan kanker mulut ini menyesatkan."

Tidak ada respons berarti seseorang tidak mempertimbangkan pesan sebagai ancaman, menganggap dirinya tidak mungkin mengalami ancaman tersebut, atau bahkan sama sekali tidak menyadari adanya ancaman.

Guna memudahkan melihat respons seseorang, Popova membuat matriks ancaman dan efficacy ${ }^{7}$, seperti berikut:

Tabel 1. Matriks Interaksi Ancaman dan Efficacy dalam Menghasilkan Proses Kontrol Bahaya dan Kontrol Rasa Takut ${ }^{7}$

\begin{tabular}{|l|l|l|}
\hline & $\begin{array}{l}\text { Efficacy tinggi: } \\
\text { Keyakinan seseorang dapat } \\
\text { menghindari ancaman }\end{array}$ & $\begin{array}{l}\text { Efficacy rendah: } \\
\text { Seseorang tidak yakin dapat } \\
\text { menghindari ancaman, jikapun bisa, } \\
\text { ia merasa tidak akan berhasil }\end{array}$ \\
\hline $\begin{array}{l}\text { Ancaman tinggi: } \\
\text { Seseorang yakin berisiko } \\
\text { tinggi mengalami ancaman }\end{array}$ & $\begin{array}{l}\text { Keseorang melakukan tindakan } \\
\text { pencegahan untuk melindungi } \\
\text { dirinya terkena ancaman }\end{array}$ & $\begin{array}{l}\text { Keseorang menolak adanya ancaman } \\
\text { dan melawannya }\end{array}$ \\
\hline $\begin{array}{l}\text { Ancaman rendah: } \\
\text { Seseorang tidak percaya suatu } \\
\text { ancaman dapat terjadi pada } \\
\text { dirinya atau menganggap } \\
\text { ancaman tersebut tidak nyata }\end{array}$ & $\begin{array}{l}\text { Kuadran III: Kontrol Bahaya } \\
\text { dalam Jumlah Sedikit Seseorang } \\
\text { melakukan tindakan } \\
\text { pencegahan, tetapi tidak terlalu } \\
\text { termotivasi melakukannya }\end{array}$ & $\begin{array}{l}\text { Kuadran IV: Tidak ada respons } \\
\text { Seseorang tidak mempertimbangkan } \\
\text { ancaman sebagai sesuatu yang nyata, } \\
\text { dapat dialami mereka, atau bahkan } \\
\text { tidak menyadari adanya ancaman }\end{array}$ \\
\hline
\end{tabular}

\section{METODE}

Penelitian ini menggunakan pendekatan kualitatif dengan jenis Rapid Assesment Procedures (RAP). Penelitian ini dilakukan di SMA Yapemri dan SMKN 2 pada bulan Januari hingga Februari, 2015. Kedua sekolah dipilih sebagai lokasi penelitian karena beberapa siswanya telah menerima intervensi penuh program berhenti merokok bernama Not on Tobacco (NOT). Sumber data penelitian adalah siswa perokok di SMA Yapemri dan SMKN 2 yang mendapat intervensi NOT dan yang tidak mendapat intervensi. Informan yang digunakan berjumlah 12 orang, yaitu 6 siswa perokok di SMA Yapemri (3 siswa yang pernah mengikuti program NOT dan 3 siswa yang tidak pernah mengikutinya) dan 6 siswa perokok di SMKN 2 (3 siswa yang pernah mengikuti program NOT dan 3 siswa yang tidak pernah mengikutinya).

Pengumpulan data dilakukan dengan metode Wawancara Mendalam (WM). Sebelum diwawancara, peneliti menunjukkan kelima PKB pada informan kemudian meminta mereka mengurutkan PKB dari yang dianggap 
paling menakutkan hingga paling tidak menakutkan. Setelah itu peneliti mengajukan pertanyaan untuk tiap gambar yang dianggap menakutkan.

Pertanyaan yang diajukan merupakan jenis pertanyaan terbuka yang sesuai dengan topik penelitian. Dengan pertanyaan terbuka, informan dapat menentukan arah jawabannya dan berkesempatan menjawab pertanyaan tersebut dari berbagai dimensi.

Analisis data dilakukan dengan mendeskripsikan informan, membuat transkrip wawancara, mengorganisasi data, mengategorisasi data, mertingkas data, mengidentifikasi variabel dan hubungan antar variabel, serta mengambil kesimpulan.

Untuk strategi pengujian validitas data dilakukan dengan triangulasi sumber dimana peneliti membandingkan dan melakukan kontras data dengan menggunakan dua kategori informan berbeda, yaitu siswa yang mendapat intervensi NOT dan siswa yang tidak mendapat intervensi.

\section{HASIL}

Dalam bab ini peneliti memaparkan rangkuman jawaban informan terhadap masing-masing tema EPPM di tiap PKB yang dianggap menakutkan yaitu PKB kanker mulut, kanker tenggorokan, dan kanker paru. Tema EPPM yang dilihat adalah rasa takut, persepsi ancaman yang terdiri dari persepsi keparahan dan persepsi kerentanan, dan persepsi keyakinan yang terdiri dari persepsi keyakinan diri dan persepsi keyakinan respon.

\section{Kanker Mulut}

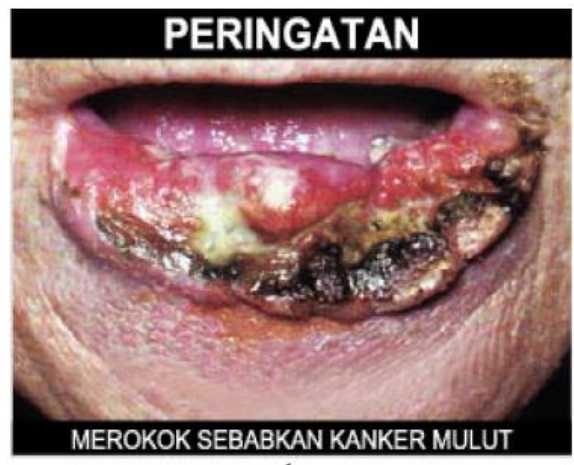

Kanker Mulut a. Rasa takut

Hampir seluruh informan, baik yang pernah mendapat intervensi maupun yang tidak, menganggap peringatan kesehatan bergambar (PKB) kanker mulut sebagai peringatan yang menakutkan. Mereka takut karena gambar ini memperlihatkan bibir yang terbakar, gosong, bernanah, bengkak, dan seperti disundut. Hal ini tergambar dari pernyataan salah satu informan:

"Itu.. bibirnya kebakar, terus ada nanah-nanah gitu. Itu agak-agak berdarah gitu.” (I5)

\section{b. Keparahan}

Hampir seluruh informan, baik yang mendapat intervensi maupun yang tidak, berpendapat bahwa kanker mulut merupakan penyakit yang parah karena dapat membahayakan hidup, menyiksa, membuat malu, dan bahkan mengakibatkan kematian. Hal ini tergambar dari pernyataan salah satu informan berikut:

"Parah sih. Jadi susah makan sama susah ngapangapain. Bikin malu juga iya. Mematikan juga iya." (I10)

\section{c. Kerentanan}

Sebagai perokok, sebagian informan yang mendapat intervensi maupun tidak, mengaku terpikir suatu saat dapat menderita kanker mulut setelah melihat PKB ini. Hal ini tergambar dari pernyataan salah satu informan berikut:

"Kalo kepikiran (terkena) iya, tapi ya jangan sampe ya kak. Ya ngebayangin aja gimana kalo kayak gitu jadinya. Mungkin udah ngga mau hidup ya kak. Hidup juga udah males. Keluar sana-sini jadi malu." (I2)

Sebagian lainnya mengaku tidak kepikiran terkena penyakit ini walaupun mereka seorang perokok. Alasannya antara lain, anggapan informan bahwa konsumsi rokoknya masih dalam batas wajar, umur informan yang masih muda, dan belum adanya bukti langsung mengenai kanker mulut yang dilihat informan: "Ohh, nggaaa (kepikiran terkena) (menjawab dengan nada yakin). Karena ini disundut, bukan gara-gara kebanyakan ngerokok kak. Menurut saya, saya ngerokoknya masih dalam batas wajar. Yang ngga wajar itu yang abis ngerokok, terus ngerokok lagi, ngerokok lagi. Terus makanannya 
diganti sama rokok." (I4)

d. Keyakinan respon

Menurut para informan, hal-hal yang dapat menjauhkan mereka dari terkena kanker mulut adalah tidur teratur, menerapkan pola makan sehat, olahraga, dan mengurangi konsumsi rokok atau berhenti merokok. Informan yang mendapat intervensi paling banyak menjawab mengurangi konsumsi rokok atau berhenti merokok, seperti pernyataan salah seorang informan berikut:

"Sama aja sih kak. Ngurangin rokok, berhenti merokok, sama olahraga." (I10)

Hal senada juga ditemukan pada informan yang tidak mendapat intervensi. Informan paling banyak menjawab mengurangi konsumsi rokok atau berhenti merokok adalah hal yang dapat menjauhkan mereka terkena kanker mulut, seperti ungkapan berikut: "Ya kurangin rokoknya kak. Jangan setiap hari, misalkan sehari itu sebatang aja. Sering olahraga juga sama makan makanan yang bergizi ya kak.” (I3)

\section{e. Keyakinan diri}

Sebagian besar informan yang mendapat intervensi meyakini mengurangi konsumsi rokok atau berhenti merokok adalah hal yang paling mudah dilakukan untuk menghindarkan mereka dari kanker mulut. Hal ini terungkap dari pernyataan informan berikut:

"(Yang paling mudah dilakukan yang) ngurangin konsumsi rokok pelan-pelan kak." (I11)

Sementara itu, seluruh informan yang tidak mendapat intervensi meyakini olahraga sebagai hal yang paling mudah dilakukan untuk menghindarkan mereka terkena kanker mulut, seperti terungkap dari pernyataan informan berikut:

"(Yang paling mudah dilakukan) olahraga kak. Kalo ngurangin rokok sulit ya kak karena yang bisa bilang diri kita berhenti merokok, cuma kita aja. Walaupun orang nyuruh berhenti berapa kali juga ga akan bisa kalo kitanya ga mau. Mungkin saya juga kecanduan sama rokok ya kak terus ketemu temen-temen yang kebanyakan ngerokok.” (I3)

Untuk keyakinan mengurangi konsumsi rokok atau berhenti merokok dengan mudah, sebagian besar informan yang mendapat intervensi mengaku yakin dapat melakukannya. Hal ini tergambar dari pernyataan informan berikut:

"Yakin banget (bisa mengurangi/berhenti merokok dengan mudah) kak, pasti bisa. Kan udah ada niat sama pendirian kuat lah kak pokoknya." (I2)

Untuk kelompok yang tidak mendapat intervensi, sebagian besar informan mengaku belum yakin dapat mengurangi konsumsi rokok atau berhenti merokok dengan mudah karena kebanyakan teman-teman sekitarnya merokok, seperti tergambar dari pernyataan informan berikut:

“..... Saat ini sih belum yakin bisa berhenti atau ngurangin ya karena temen-temen juga mayoritas ngerokok.” (I5)

\section{Kanker Tenggorokan}

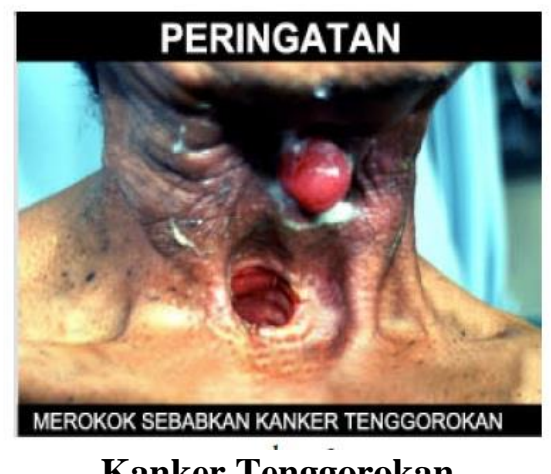

a. Rasa takut

Seluruh informan, baik yang mendapat intervensi maupun tidak, menganggap PKB kanker tenggorokan sebagai peringatan yang menakutkan. Hal yang membuat mereka takut adalah tenggorokan yang bolong dan amandel yang keluar, seperti terungkap dari pernyataan informan berikut:

"Serem nih kak. Tenggorokannya bolong bikin nafas jadi susah. Ini amandelnya juga keluar.” (I8)

b. Keparahan

Hampir seluruh informan, baik yang mendapat intervensi maupun tidak, menganggap kanker tenggorokan sebagai penyakit yang parah karena dapat membuat hidup menderita, malu, dan bahkan mematikan. Hal ini tergambar dari pernyataan berikut:

"Parah banget deh kak. Soalnya kan dokter juga kan mungkin belum bisa ya memperbaiki lehernya 
kayak semula. Nyiksa juga pasti, soalnya kan kemana-mana pake selang. Bahkan bisa mematikan juga nih kak." (I6)

Hanya seorang informan dari kelompok yang tidak mendapat intervensi beranggapan bahwa penyakit ini tidak terlalu parah karena masih bisa diobati.

c. Kerentanan

Sebagian besar informan, baik yang mendapat intervensi maupun tidak, mengaku terpikir suatu saat dirinya mungkin menderita kanker tenggorokan setelah melihat gambar ini:

"Bisa juga, kepikiran (terkena) juga. Soalnya kan asep rokok kan masuk ke paru-paru lewat tenggorokan. Jadi kalo misalnya makin lama ngerokok kan asepnya ngumpul di tenggorokan, bisa sampe kayak gini." (I9)

Sementara itu, sebagian informan lainnya (mayoritas berasal dari kelompok yang mendapat intervensi), mengaku tidak terpikir suatu saat dapat mengalami kanker tenggorokan.

d. Keyakinan respon

Menurut sebagian besar informan, baik yang mendapat intervensi maupun tidak, kanker tenggorokan dapat dihindari dengan menerapkan pola makan sehat, olahraga, dan mengurangi konsumsi rokok atau berhenti merokok.

"Ya itu tadi. Kurangin rokok, berhenti merokok, sama olahraga.” (I10)

Dalam penelitian ini juga ditemukan seorang informan dari kelompok yang tidak mendapat intervensi, mengaku pasrah jika suatu saat terkena kanker tenggorokan karena menurutnya hal tersebut adalah risiko yang harus ditanggung ketika dirinya memilih jadi perokok, seperti pernyataannya berikut: "Ya itu... Tawakal aja. Kalo misalkan kena, yaudah. Kalo ngga, yaudah. Kalo kena ya ibaratnya udah risiko saya." (I4)

e. Keyakinan diri

Dari berbagai hal yang menurut para informan dapat menjauhkan mereka dari penyakit kanker tenggorokan, sebagian besar informan berpendapat bahwa olahraga merupakan hal yang mereka yakini paling mudah dilakukan. Sebagian kecil lainnya mengatakan mengurangi atau berhenti merokok merupakan hal yang paling mudah dilakukan, seperti pernyataan informan berikut:

"(Yang paling mudah dilakukan) yang ngurangin rokok kak. Soalnya kan udah pernah saya coba juga." (I10)

Untuk keyakinan mengurangi konsumsi rokok atau berhenti merokok dengan mudah, sebagian besar informan yang mendapat intervensi yakin dapat melakukannya:

"Yakin banget kak. Pasti bisa

(mengurangi/berhenti merokok dengan mudah) kok." (I6)

Sementara itu, sebagian besar informan yang tidak mendapat intervensi mengaku belum terlalu yakin dapat mengurangi konsumsi rokok atau berhenti merokok dengan mudah :

"Hmmm... 50 persen tadi kak. Ga terlalu yakin (bisa mengurangi/berhenti merokok dengan mudah) karena kebanyakan temen memang ngerokok.” (I3)

\section{Kanker Paru}

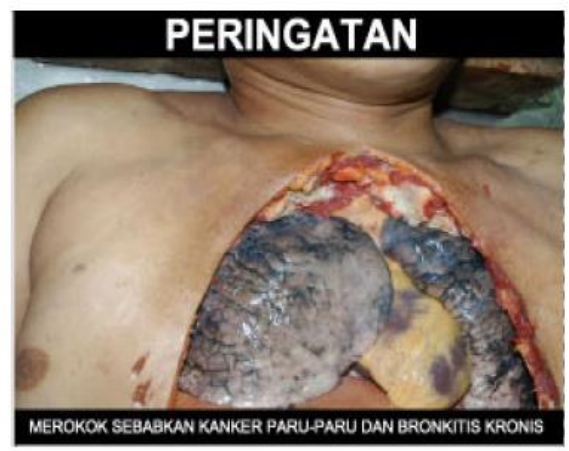

Kanker Paru

a. Rasa takut

Seluruh informan, baik yang mendapat intervensi maupun tidak, menganggap PKB kanker paru sebagai gambar yang menakutkan. Hal-hal yang membuat mereka takut adalah paru-paru yang menghitam, paru-paru yang luka/bernanah, dan bagian dada yang dibelek. Berikut ungkapan salah seorang informan: "Itu paru-parunya, ada lukanya, sampe item-item gitu. Dibelek juga bikin serem." (I9)

b. Keparahan 
Seluruh informan baik yang mendapat intervensi maupun tidak, berpendapat bahwa kanker paru merupakan penyakit yang parah karena dapat membahayakan hidup, menyiksa, dan bahkan mematikan.

"Parah kak... Itu bisa nyakitin pernafasan sendiri... Terganggu lah pernafasan... Membuat orang menderita juga kak, sampe bisa meninggal juga kan gara-gara ini." (I5)

c. Kerentanan

Sebagian besar informan yang mendapat intervensi maupun tidak, mengaku pernah terpikir suatu saat dirinya mungkin mengalami kanker paru akibat merokok setelah melihat gambar ini. Hal ini terungkap dari pernyataan informan berikut:

"Kepikiran (terkena) kak. Pastilah. Kepikiran bisa aja suatu saat terjadi sama saya yang ngerokoknya berat gitu kak." (I7)

Sementara itu, sebagian kecil informan (mayoritas berasal dari kelompok yang tidak pernah mendapat intervensi) mengaku tidak pernah terpikir bisa mengalami kanker paru karena menurut informan konsumsi rokoknya masih wajar, umurnya masih muda, dan belum ada bukti langsung yang informan lihat.

"Ngga pernah (kepikiran terkena), saya ga pernah mikirin kayak gitu. Soalnya kan masih muda juga. Ga mungkin kena yang kayak gini." (I12)

d. Keyakinan respon

Menurut sebagian besar informan, baik yang mendapat intervensi maupun tidak, kanker paru dapat dihindari dengan menerapkan pola makan sehat, olahraga, dan mengurangi konsumsi rokok atau berhenti merokok. Dalam penelitian ini juga diketahui seorang informan yang berasal dari kelompok yang tidak diintervensi, mengatakan tidak mungkin dapat terhindar dari kanker paru karena merokok.

"Kalo misalkan paru-paru, otomatis kan asep rokok masuk kesini. Jadi ga mungkin aja dihindarin gitu." (I4)

e. Keyakinan diri

Dari berbagai hal yang menurut informan dapat menjauhkannya dari kanker paru, sebagian besar informan meyakini olahraga merupakan hal yang paling mudah dilakukan, seperti ungkapan seorang informan berikut:
"(Yang paling mudah dilakukan yang) olahraga. Paling dua hari sekali. Fitness sama lari pagi gitu kak.” (I12)

Sementara itu, sebagian kecil informan berpendapat bahwa mengurangi konsumsi rokok merupakan hal yang mereka yakini paling mudah dilakukan.

"Yang (paling mudah dilakukan yang) kurangin rokok soalnya udah saya lakuin." (I10)

Untuk keyakinan mengurangi konsumsi rokok atau berhenti merokok, sebagian besar informan (mayoritas berasal dari kelompok yang mendapat intervensi) merasa yakin dapat mengurangi atau berhenti merokok dengan mudah, seperti ungkapan seorang informan berikut:

"Yakin banget (bisa berhenti/mengurangi rokok dengan mudah) kak. Sekarang udah punya, apa ya namanya, pendirian gitu kak. Pendirian pingin berhenti. Ada niat kuat juga untuk berhenti merokok." (I2)

Sementara itu, sebagian kecil informan (berasal dari kelompok yang tidak mendapat intervensi) belum merasa yakin dapat mengurangi atau berhenti merokok dengan mudah. Hal ini tergambar dari ungkapan salah satu informan berikut:

"Masih setengah yakin (bisa berhenti/mengurangi rokok dengan mudah) ya kak, soalnya ya itu tadi, temen-temen kebanyakan ngerokok. Kalo lagi ngumpul bareng juga ngga mungkin ngga ngerokok. Jadi sulit gitu untuk berhenti atau ngurangin rokok kalo masih sama temen-temen yang emang perokok." (I3)

\section{DISKUSI}

Dalam bab ini peneliti membahas apakah tema-tema penelitian yang muncul dari ketiga peringatan bergambar penyakit, sesuai dengan konsep Extended Parallel Process Model (EPPM) oleh Kim Witte.

a. Rasa Takut

Secara umum, jawaban-jawaban informan mengenai rasa takut yang ditimbulkan dari peringatan bergambar penyakit sesuai dengan konsep rasa takut seperti yang didefinisikan oleh Witte dalam teori EPPM. ${ }^{6} \mathrm{Hal}$ ini tergambar dari jawaban para informan yang mengarah 
pada reaksi emosional internal, seperti perasaan "takut," "seram," "ngeri," dan "jijik," ketika diperlihatkan ketiga peringatan bergambar penyakit.

Untuk pola jawaban informan, tidak terlihat adanya perbedaan antara kelompok yang mendapat intervensi dengan kelompok yang tidak mendapat intervensi. Hampir seluruh informan dari kedua kelompok menganggap ketiga peringatan bergambar penyakit sebagai gambar yang menakutkan. Bila dilihat dari urutan jawaban informan mengenai gambar yang menakutkan, gambar yang menempati urutan teratas (membuat informan paling takut) adalah gambar kanker paru. Posisi kedua ditempati gambar kanker mulut, dan yang terakhir adalah gambar kanker tenggorokan.

b. Persepsi Keparahan

Secara umum, jawaban-jawaban informan mengenai tingkat keparahan dari penyakit yang terdapat dalam peringatan bergambar sesuai dengan konsep persepsi keparahan seperti yang didefinisikan oleh Witte dalam teori EPPM. ${ }^{6}$ Jawaban informan mengarah pada keyakinan mereka mengenai signifikansi dan besaran ancaman yang ditunjukkan ketiga peringatan bergambar penyakit, seperti dapat "membahayakan hidup," "menyiksa," "membuat hidup menderita," "membuat malu," hingga "mematikan." Persepsi keparahan ini juga tergambar dari pendapat informan bila seseorang mengalami penyakit yang ditunjukkan dalam PKB, seperti dapat "menyulitkan hidup," "menderita," dan "menyusahkan keluarga."

Untuk pola jawaban informan, tidak terlihat adanya perbedaan antara kelompok yang mendapat intervensi dengan yang tidak. Hampir seluruh informan dari kedua kelompok menganggap ketiga peringatan bergambar penyakit menunjukkan suatu keparahan.

c. Persepsi Kerentanan

Secara umum, jawaban-jawaban informan mengenai kerentanan mereka akan terkena penyakit yang terdapat dalam peringatan bergambar sesuai dengan konsep persepsi kerentanan seperti yang didefinisikan oleh Witte dalam teori EPPM. ${ }^{6}$ Jawaban informan mencerminkan keyakinan atas risiko dirinya mengalami ancaman seperti yang ditunjukan ketiga peringatan bergambar penyakit, seperti "tidak yakin terkena," "yakin mungkin terkena," hingga "sangat yakin terkena." Tidak seperti pada tema rasa takut dan persepsi keparahan, pada tema persepsi kerentanan terlihat perbedaan pola jawaban antar kelompok yang mendapat intervensi dengan yang tidak. Perbedaan tersebut muncul pada PKB kanker mulut dan kanker tenggorokan.

d. Persepsi Keyakinan Respon

Ketiga peringatan bergambar penyakit yang beredar pada putaran pertama tidak memiliki pesan rekomendasi bagi perokok untuk berhenti merokok. Pesan kesehatan yang tercantum hanya menunjukkan dampak negatif akibat merokok, seperti "Merokok Sebabkan Kanker Mulut." Pada penelitian ini, komponen persepsi keyakinan respon berusaha menggali halhal apa saja yang dianggap informan dapat dilakukan untuk menghindari ancaman yang ditunjukkan ketiga peringatan bergambar penyakit. Berbagai jawaban yang muncul antara lain, menerapkan pola makan sehat, olahraga, dan mengurangi konsumsi rokok atau berhenti merokok.

Secara umum, tidak ditemukan adanya perbedaan pola jawaban pada informan di kelompok yang mendapat intervensi dengan yang tidak. Sebagian besar informan meyakini dengan menerapkan pola makan sehat, olahraga, dan mengurangi konsumsi rokok atau berhenti merokok, dirinya dapat terhindar dari penyakit yang ditunjukkan ketiga PKB.

e. Persepsi Keyakinan Diri

Dalam tema ini ditanyakan tentang seberapa yakin informan dapat mengurangi konsumsi rokok atau berhenti merokok dengan mudah. Jawaban yang munculpun 
terlihat bervariasi, seperti tidak yakin, agak yakin, yakin, hingga sangat yakin.

Secara umum, terlihat adanya perbedaan pola jawaban pada informan kelompok yang mendapat intervensi dengan yang tidak. Sebagian besar informan pada kelompok yang mendapat intervensi mengatakan yakin dan sangat yakin dapat mengurangi konsumsi rokok atau berhenti merokok dengan mudah. Sedangkan pada kelompok yang tidak mendapat intervensi, sebagian besar informan merasa tidak yakin dan agak yakin dapat mengurangi konsumsi rokok atau berhenti merokok dengan mudah. Bila disimpulkan, terdapat perbedaan persepsi keyakinan (keyakinan respon dan keyakinan diri) antara informan pada kelompok yang mendapat intervensi dengan yang tidak. Informan pada kelompok yang mendapat intervensi memiliki keyakinan diri yang lebih tinggi untuk dapat mengurangi konsumsi rokok atau berhenti merokok dengan mudah dibandingkan informan yang tidak mendapat intervensi.

f. Motivasi Protektif-Proses Kontrol Bahaya

Dalam EPPM, motivasi protektif dan proses kontrol bahaya adalah bagian yang saling berkaitan. Menurut Popova, proses kontrol bahaya adalah proses kognitif yang memunculkan motivasi protektif, terjadi ketika seseorang meyakini dirinya dapat menghindari sebuah ancaman lewat perubahan diri yang bersifat protektif. ${ }^{7}$

Sebagian besar informan pada kelompok yang mendapat intervensi dominan berada pada proses kontrol bahaya kuadran satu. Bentuk penerimaan pesan terlihat antara lain dengan perubahan sikap informan terhadap perilaku merokok dan perubahan niat informan berupa rencana berhenti merokok. Pada kelompok yang tidak mendapat intervensi, hanya sebagian kecil informan yang dominan berada pada proses kontrol bahaya. Mereka berada pada kuadran tiga karena memiliki keyakinan yang tinggi untuk dapat mengurangi konsumsi rokok atau berhenti merokok dengan mudah, namun persepsi ancamannya terhadap ketiga penyakit terbilang rendah. Mereka merasa tidak berisiko mengalami penyaki tersebut karena anggapan konsumsi rokoknya masih dalam batas wajar serta umurnya yang masih muda. Walaupun begitu, para informan tetap menunjukkan penerimaan pesan. Hal ini ditandai dengan usaha informan untuk secara perlahan mengurangi konsumsi rokok.

g. Motivasi Defensif - Proses Kontrol Rasa Takut

Sama halnya dengan motivasi protektif dan proses kontrol bahaya, motivasi defensif dan proses kontrol rasa takut juga merupakan bagian yang saling berkaitan dalam EPPM. Proses kontrol rasa takut adalah proses emosional yang memunculkan motivasi defensif, terjadi ketika seseorang dihadapkan pada ancaman yang serius dan mungkin terjadi pada dirinya, namun seseorang tidak yakin dapat melakukan tindakan yang direkomendasikan atau dirinya tidak yakin tindakan tersebut efektif.?

Pada kelompok yang mendapat intervensi, hanya seorang informan yang dominan berada pada proses kontrol rasa takut. Pada kelompok yang tidak mendapat intervensi, sebagian besar informan terlihat lebih didominasi oleh motivasi defensif. Para informan memiliki persepsi ancaman yang tinggi, namun keyakinannya untuk dapat mengurangi konsumsi rokok atau berhenti merokok terbilang rendah.Perasaan takut yang dialami informan membuat mereka mengembangkan motivasi defensif yang berujung pada upaya-upaya penolakan pesan, misalnya dengan menghindari melihat peringatan bergambar seram atau menanggapi pesan yang dianggap berlebihan dengan candaan.

\section{Kesimpulan}

Berdasarkan penelitian mengenai peran kesan menakutkan pada peringatan kesehatan bergambar (PKB) di bungkus rokok yang telah 
dilakukan di SMA Yapemri dan SMKN 2

Depok, dapat disimpulkan bahwa:

1. Rasa Takut

a. Hampir seluruh informan, baik yang mendapat intervensi maupun tidak, merasa takut dengan ketiga PKB penyakit (kanker mulut, kanker tenggorokan, dan kanker paru) karena memperlihatkan bagian tubuh yang tidak normal.

b. Sebagian besar informan, baik yang mendapat intervensi maupun tidak, merasa ngeri, jijik, atau tidak nyaman ketika melihat PKB berupa penyakit akibat merokok.

c. Tema rasa takut yang muncul dalam penelitian ini sesuai dengan konsep fear dalam EPPM.

2. Persepsi Ancaman

a. Hampir seluruh informan, baik yang mendapat intervensi maupun tidak, menganggap ketiga PKB penyakit menunjukkan suatu keadaan yang parah karena dapat membahayakan hidup, menyiksa, membuat hidup menderita, membuat malu, hingga mematikan.

b. Sebagian besar informan, baik yang mendapat intervensi maupun tidak, merasa dirinya suatu saat dapat terkena penyakit yang ditunjukkan ketiga PKB.

c. Tema persepsi keparahan yang muncul dalam penelitian ini sesuai dengan konsep perceived threat dalam EPPM oleh Kim Witte.

3. Persepsi Keyakinan

a. Sebagian besar informan, baik yang mendapat intervensi maupun tidak, meyakini bahwa mengurangi konsumsi rokok atau berhenti merokok, berolahraga, dan menerapkan pola makan seimbang, adalah hal-hal yang dapat menjauhkan diri mereka dari ketiga penyakit dalam PKB.

b. Sebagian besar informan pada kelompok yang mendapat intervensi memiliki keyakinan yang lebih tinggi untuk dapat mengurangi konsumsi rokok atau berhenti merokok dengan mudah dibandingkan dengan informan dari kelompok yang tidak mendapat intervensi.

c. Tema persepsi keyakinan dalam penelitian ini tidak merujuk pada konsep perceived efficacy dalam EPPM oleh Kim Witte. Hal ini dikarenakan PKB di Indonesia belum memiliki komponen efficacy berupa pesan rekomendasi bagi perokok.

4. Motivasi Protektif - Proses Kontrol Bahaya

a. Sebagian besar informan yang mengembangkan motivasi protektif dan dominan berada pada proses kontrol bahaya berasal dari kelompok yang mendapat intervensi.

b. Bentuk penerimaan pesan PKB terlihat dari perubahan niat, sikap, dan perilaku informan berkaitan dengan kebiasaan merokoknya.

c. Tema motivasi protektif yang muncul dalam penelitian ini sesuai dengan konsep protection motivation dalam EPPM.

5. Motivasi Defensif - Proses Kontrol Rasa Takut

a. Sebagian besar informan yang mengembangkan motivasi defensif dan dominan berada pada proses kontrol rasa takut berasal dari kelompok yang tidak mendapat intervensi.

b. Bentuk penolakan pesan PKB terlihat dari perilaku menghindari melihat $\mathrm{PKB}$ oleh informan, seperti merobek gambar penyakit atau membeli secara ketengan.

c. Tema motivasi defensif yang muncul dalam penelitian ini sesuai dengan konsep defensive motivation dalam EPPM.

\section{Saran}

1. Saran bagi Kementerian Kesehatan

a. Untuk PKB putaran kedua di Indonesia, gambar menakutkan masih dapat dipakai karena hasil penelitian ini menunjukkan gambar menakutkan dianggap lebih efektif meningkatkan kesadaran remaja akan bahaya merokok dan lebih meyakinkan mereka untuk 
berhenti merokok daripada gambar simbolis. Oleh karena itu, putaran kedua PKB di Indonesia sebaiknya hanya menampilkan gambar-gambar yang menakutkan saja.

b. Hampir seluruh informan dalam penelitian ini masih memiliki anggapan kurang tepat mengenai hal-hal yang dapat menjauhkan mereka dari bahaya merokok, seperti menerapkan pola makan sehat dan berolahraga. Hal ini kemungkinan karena pada PKB putaran pertama hanya berisi pesan dan gambar dari risiko merokok saja. Untuk putaran berikutnya, kiranya perlu menambahkan pesan mengenai keuntungan dari berhenti merokok, tips untuk berhenti merokok, serta pesan yang memotivasi untuk berhenti merokok seperti yang telah dipakai di Kanada atau Australia.

2. Saran bagi Peneliti Selanjutnya Meskipun tema-tema yang ditemukan dalam penelitian ini sejalan dengan komponen dalam teori EPPM, pendekatan kualitatif yang digunakan tidak mampu menunjukkan hubungan antara tema-tema tersebut secara akurat. Untuk itu, penelitian dengan pendekatan kuantitatif perlu dilakukan agar hubungan antar variabel (misalnya, rasa takut dengan persepsi ancaman) atau pengaruh dari variabel satu ke variabel lain (misalnya, pengaruh persepsi keyakinan terhadap pengendalian bahaya) dapat diketahui secara lebih akurat. Penelitian lanjutan dengan pendekatan kuantitatif juga akan lebih mampu menjangkau target populasi yang lebih luas dan lebih beragam dari sisi geografi (urbanrural), kelompok usia (remaja-dewasa), pendidikan, maupun ekonomi. Penelitian kuantitatif dengan desain eksperimen juga diperlukan untuk mengujicoba apakah peringatan bergambar dengan pesan efikasi dapat lebih meningkatkan persepsi efikasi dibandingkan dengan peringatan kesehatan tanpa pesan efikasi.

\section{Daftar Referensi}

1. Pusat Penelitian Kesehatan Universitas Indonesia. (2012). Survei Penyalahgunaan dan Peredaran Gelap Narkoba pada Kalangan Pelajar/Mahasiswa di Kota Depok. Depok: PPK UI.

2. Anggun, K., Damayanti, R., \& Rachmanto, N. (2013). "Not on Tobbaco" Program to Help Teenagers Quit Smoking in Depok, West Java. Depok: Pusat Penelitian Kesehatan UI.

3. Kementerian Kesehatan. (2012). Peraturan Pemerintah Republik Indonesia Nomor 109 Tahun 2012. Jakarta: Kementerian Kesehatan.

4. Kementerian Kesehatan. (2013). Peraturan Menteri Kesehatan Republik Indonesia Nomor 28 Tahun 2013. Jakarta: Kementerian Kesehatan.

5. Witte, K. (1992). Putting the Fear Back Into Fear Appeals: The Extended Parallel Process Model. Communication Monographs , 330-349.

6. Witte, K. (1994). Fear Control and Danger Control: A Test of the Extended Parallel Process Model (EPPM). Communication Monographs , 113-134.

7. Popova, L. (2012). The Extended Parallel Process Model: Illuminating the Gaps in Research. Sage Journals Volume 39 No.4 , 455473. 